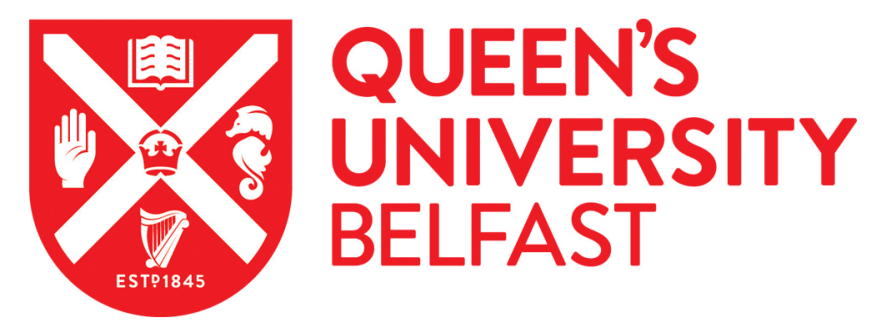

\title{
Remain reaffirmed: the 2019 European election in Northern Ireland
}

Haughey, S., \& Pow, J. (2019). Remain reaffirmed: the 2019 European election in Northern Ireland. Irish Political Studies. https://doi.org/10.1080/07907184.2019.1652166

\author{
Published in: \\ Irish Political Studies
}

\section{Document Version:}

Peer reviewed version

\section{Queen's University Belfast - Research Portal:}

Link to publication record in Queen's University Belfast Research Portal

\section{Publisher rights}

Copyright 2019 Taylor and Francis. This work is made available online in accordance with the publisher's policies. Please refer to any applicable terms of use of the publisher.

\section{General rights}

Copyright for the publications made accessible via the Queen's University Belfast Research Portal is retained by the author(s) and / or other copyright owners and it is a condition of accessing these publications that users recognise and abide by the legal requirements associated with these rights.

Take down policy

The Research Portal is Queen's institutional repository that provides access to Queen's research output. Every effort has been made to ensure that content in the Research Portal does not infringe any person's rights, or applicable UK laws. If you discover content in the Research Portal that you believe breaches copyright or violates any law, please contact openaccess@qub.ac.uk. 


\title{
Remain Reaffirmed: The 2019 European election in Northern Ireland
}

\author{
Sean Haughey* and James Pow**
}

Report accepted for publication in Irish Political Studies

Published online on 28 October 2019

* Institute of Irish Studies, School of Histories, Languages and Cultures, University of Liverpool, Liverpool, UK

**School of History, Anthropology, Philosophy and Politics, Queen’s University Belfast, Belfast, UK 


\begin{abstract}
With echoes of the dividing lines of the United Kingdom's 2016 referendum, a majority of voters in Northern Ireland supported pro-Remain candidates in the 2019 European Parliament election. However, whereas the results in many parts of the UK reflected a highly polarised electorate, voters in Northern Ireland appeared more receptive to compromise: a majority of their newly elected MEPs expressed support for the Withdrawal Agreement negotiated by the UK government with the EU - the only constituency in the UK where this was the case. The comfortable re-election of Diane Dodds and Martina Anderson affirmed the Democratic Unionist Party and Sinn Féin as the dominant unionist and nationalist parties respectively. However, a surge in support for the Alliance Party, which saw Naomi Long win a seat at the expense of the Ulster Unionist Party, marked a notable shift towards the ethno-national centre-ground: one in five first preference votes went to a candidate aligned with neither nationalism nor unionism. This report contextualises the election campaign and considers the implications of the results.
\end{abstract}

Keywords: Europe; European elections; political parties; Northern Ireland; Brexit; Withdrawal Agreement 


\section{Background}

Political developments at multiple levels of government combined to create a context to the 2019 European election in Northern Ireland that was radically different to its predecessor in 2014. At the national level, the 2016 referendum result in favour of the UK leaving the European Union had the effect of catapulting Northern Ireland onto the centre stage of British politics. The Irish border, which did not feature prominently in the Leave and Remain campaigns in Britain, soon became the issue of Brexit as Parliament and the UK Government grappled with the complex (if not impossible) task of removing Northern Ireland from the European single market and customs union without hardening the border with the Republic of Ireland. Indicative of Northern Ireland's increased prominence in mainstream British politics, senior UK politicians, from Labour Party leader Jeremy Corbyn to Conservative Party grandee Jacob Rees-Mogg, have felt the need to make well-publicised visits to towns and villages along its border. High profile visitors from further afield, including US House of Representatives Speaker Nancy Pelosi, suggest that the fate of Northern Ireland's post-Brexit future also features on political agendas elsewhere. As the region of the UK set to be most distinctly affected by Brexit (Tonge, 2017a), and one with a recent history of ethno-national conflict, all eyes within and without the UK were on Northern Ireland in the run-up to its ninth European election.

At the regional level, the election took place against a backdrop of near recordbreaking political stalemate. ${ }^{\mathrm{i}}$ This is because Northern Ireland had been without devolved government since January 2017 after the resignation of then deputy First Minister Martin McGuinness over, amongst other things, the DUP's involvement in an energy policy scandal. This power vacuum in Northern Ireland has severely handicapped the region's ability to prepare for Brexit. Whereas the devolved administrations in Scotland and Wales have conducted detailed scrutiny of the potential implications of EU withdrawal for their 
respective jurisdictions, there have been no such efforts in Northern Ireland for over two years. ${ }^{\text {ii }}$ With there being no functioning Assembly or Executive, Northern Ireland has been unrepresented on the Interparliamentary Forum on Brexit, a body established to facilitate collective scrutiny of EU withdrawal by the UK's legislatures, and the UK's Joint Ministerial Committee, set up to coordinate relationships between the devolved administrations and the UK Government. ${ }^{\text {iii }}$ Members of the Assembly (MLAs), who continue to hold office, have expressed frustration at Northern Ireland's lack of a formal, collective voice in these discussions (Manley, 2017). ${ }^{\text {iv }}$

The inability of most of Northern Ireland's political parties to contribute to Brexit deliberations has stood in stark contrast to the remarkably powerful position occupied by the Democratic Unionist Party. Since the snap 2017 General Election, in which Theresa May lost her parliamentary majority, the DUP has sustained the Conservatives in office through a Confidence and Supply Agreement. This arrangement has afforded the DUP unprecedented leverage over the minority government, which depends on the votes of 10 DUP MPs for its survival. ${ }^{\mathrm{V}}$ The DUP's continued opposition to the 'Irish backstop' - a contingency plan for avoiding a hard border should the UK leave the EU without a comprehensive trade agreement - was a major factor behind Mrs May’s failure to get the Withdrawal Agreement through the House of Commons. ${ }^{\text {vi }}$ Widespread support in Northern Ireland for the Agreement - as expressed by business leaders (McGrath, 2019), the farming community (O’Carroll, 2019), and opinion polls (McMordie, 2018) - did not weaken the DUP's resolve. Given the propensity for prominent Brexiteers to follow the DUP's lead on the Withdrawal Agreement, it is not inconceivable that a softening of the party's position on the backstop would have encouraged sufficient parliamentary support for the deal to pass, ensuring the UK's orderly exit from the EU on $29^{\text {th }}$ March 2019. ${ }^{\text {vii }}$ As things transpired, the House of Commons voted against the Withdrawal Agreement on three separate occasions, resulting in a delay in the 
UK's scheduled departure which, in turn, required the UK to hold European Parliament elections alongside the 27 continuing member states. The vote took place on $23^{\text {rd }}$ May 2019. ${ }^{\text {viii }}$

Parties in Northern Ireland were able to hit the ground running, having only just run the gauntlet of local government elections three weeks previously. The Northern Ireland council elections, held on $2^{\text {nd }}$ May 2019, had more than a few surprising results. Although the DUP and Sinn Féin maintained their positions as the dominant players of their respective ethno-national communities, the story of the local elections belonged to those parties in Northern Ireland who reject unionist and nationalist identity politics altogether. Increasing its vote share by 4.8 percentage points, with a gain of 21 council seats, the Alliance Party's impressive performance seemed to take even its own members by surprise (Bradshaw, 2019). Advances made by other ethno-nationally centrist parties, such as the Greens and People Before Profit, suggested the awakening of a new kind of politics in the region and led one academic to conclude that the hitherto elusive creature of 'non-unionist, non-nationalist elector' in Northern Ireland 'really does exist' (Tonge, 2019). For the Alliance Party in particular, whose leader Naomi Long had already announced her intention to run for MEP in April 2019, this surge in the so-called 'centre ground' vote raised hopes that, for the first time, one of Northern Ireland's European Parliament seats could be won by a crosscommunity candidate..$^{\text {ix }}$ 


\section{Campaign}

At 16 days in total, the official campaign period for the 2019 European election was short indeed. By virtue of the recent council elections, parties in Northern Ireland were able to enter the European race with immediate momentum, with several announcing their MEP candidates during the local government campaign. Eleven candidates in total contested Northern Ireland's three seats, making the 2019 election the most crowded contest since 1994. Incumbent candidates Diane Dodds of the Democratic Unionist Party (DUP) and Martina Anderson of Sinn Féin were joined in the race by Danny Kennedy of the Ulster Unionist Party (UUP), Colum Eastwood of the Social Democratic and Labour Party (SDLP), Naomi Long of the Alliance Party, Jim Allister of the Traditional Unionist Voice (TUV), Clare Bailey of the Green Party, Robert Hill of the United Kingdom Independence Party (UKIP), and Amandeep Singh Bhogal of the Northern Ireland Conservatives, re-branded as the 'Conservative and Unionist Party'. Two independent candidates, Jane Morrice and Neil McCann, also contested the election.

Opinion polls identified candidates from Northern Ireland's five main parties - the DUP, Sinn Féin, SDLP, UUP, and the Alliance Party - as frontrunners in the race (McMordie, 2019). Each of these candidates, alongside former MEP and TUV candidate Jim Allister, had the opportunity to make their case during three televised debates, two hosted by the BBC and a third by UTV. Social media, however, was by far and away the dominant medium through which the candidates broadcast their message. Whilst all candidates made use of Twitter in their campaigns, it was more useful to some candidates than others given their respective followings. With over 40,000 followers on Twitter, for example, Alliance candidate Naomi Long's social media audience dwarfed that of rival Danny Kennedy (UUP), whose followers numbered fewer than 3,000. Sinn Féin’s Martina Anderson fully capitalised on her large social media following by tweeting regular videos whilst on the campaign trail, a 
strategy that others increasingly made use of towards the end of the campaign. Each contender advocated either one of two positions: that Northern Ireland should leave the EU on the same terms as Great Britain, or that Northern Ireland should not leave at all.

For the DUP, Northern Ireland's future in the United Kingdom was at stake in this election. The party's manifesto outlined five reasons to vote for its candidate Diane Dodds, the first of which was to 'defend the Union and oppose a border poll' (DUP, 2019a). A vote for the DUP, so the party argued, was a vote for delivering a Brexit in which all constituent parts of the UK exited the EU on the same terms. Any alternative to this, namely a Withdrawal Agreement that included the Irish backstop, was framed as a threat to 'our precious union' (ibid). The argument that it is Brexit which has endangered the Union, by increasing calls for a referendum on Irish unity (McCormack, 2019) and by breathing new life into Scottish separatism (Financial Times, 2019), was not entertained by the party. The DUP was also dismissive of the argument that Northern Ireland had voted by a margin of 56 percent to remain and, as such, its withdrawal from the EU would lack democratic legitimacy at the regional level (see Tonge, 2016). Diane Dodds's campaign slogan of 'Tell Them Again!', an encouragement to voters to reaffirm the 2016 referendum result to leave, was turned on its head by the BBC's Mark Caruthers, who put it to Dodds that Northern Ireland voters could well tell her again that they do not want Brexit. ${ }^{\mathrm{x}}$ Unperturbed, Dodds repeated her manifesto line that the 2016 referendum was not a Northern Irish vote, nor a Scottish, Welsh, or English vote, but a vote of the people of the United Kingdom.

The DUP party election broadcast made a virtue of Diane Dodds’s history of working with organisations such as the Shankill Women's Centre, a beneficiary of the European Regional Development Fund, and the Kilcooley Women's Centre, whose projects have been funded by the European Social Fund (DUP, 2019b). How organisations such as these will fund their projects in the absence of European funding was not discussed, although the 
party's manifesto does suggest that women's sector funding may become available via Northern Ireland's share of the 'Brexit Dividend' once the UK leaves the EU (DUP, 2019a: 27). Dodds's performance in the televised debates will have pleased the party faithful, with clips of her denouncement of the Irish backstop being widely circulated among supporters on Twitter. Unlike the 2014 European election campaign, Dodds did not have to contend with full frontal attacks from the TUV's Jim Allister, who, not wanting to undermine fellow Brexiteers, refrained from his usual scathing criticism of the DUP. Criticism of Dodds did, however, come from elsewhere. Her decision to share on social media a pro-Brexit video which used footage of Troubles-era violence in its case against the Irish backstop was branded as 'crass in the extreme' (Hughes, 2019). However, in a deeply divided society still emerging from conflict, there is mileage to be had from emotionally charged ethnic appeals such as these.

The UUP entered the race with a lot to lose. The party’s veteran MEP Jim Nicholson, successful in six consecutive European elections (1989-2014), announced in April 2019 that he would not be standing for re-election, leading to speculation that the seat long-held by the UUP was now up for grabs. This announcement came at a difficult time for the UUP, having lost seats in the last Assembly, Westminster, and council elections. The job of reversing the party’s downward electoral spiral was given to Danny Kennedy, a former MLA and casualty of the 2017 Assembly election. The UUP's journey with regards to Brexit was reflected in its choice of MEP candidate. Although the party declared its support for the UK remaining in the EU in 2016, it has since argued for the implementation of the referendum result via a ‘sensible Brexit' (UUP, 2019). ${ }^{x i}$ In similar fashion, Kennedy’s position evolved from one that warned about the economic and constitutional dangers of Brexit (Kennedy, 2016), to one that insisted upon Northern Ireland's departure from the EU as per the 2016 referendum result. 
Of the three unionist candidates, Kennedy's debate performances were by far the most subdued. Unlike Diane Dodds and Jim Allister, ardent Brexiteers who extolled the virtues of Brexit and argued passionately for Northern Ireland leaving the EU come what may, there were no ringing endorsements of Brexit from Kennedy, who instead advocated a nuanced position that was vulnerable to attack from all sides. Evidently, Kennedy perceived the biggest threat to his election as coming from the SDLP's Colum Eastwood and Alliance's Naomi Long. In a rare offensive move, Kennedy suggested during the UTV debate that, as leaders of their respective parties, Eastwood and Long seemed intent on 'abandoning' their responsibilities at Stormont to fulfil their own ambitions in Europe. ${ }^{\text {xii }}$ It was an odd challenge to make, given that the devolved institutions had collapsed in 2017 , and duly fell flat. In contrast to Diane Dodds and, in particular, Jim Allister, Kennedy’s attacks on the anti-Brexit candidates were somewhat lacklustre. Failing to lay a glove on the Remain candidates, and outshone by Brexiteers Dodds and Allister, Kennedy struggled to make his mark.

The same could not be said of the Alliance Party candidate Naomi Long, who entered the race on a high following her party's impressive local election performance. In her EU election broadcast, and in her debate performances, Long made an unapologetic case in favour of a second Brexit referendum (branded a 'People's Vote'). Brexit, she argued, had paralysed politics in Northern Ireland, threatened its jobs, and risked the UK's ability to respond to global challenges such as climate change and peace and security (Alliance Party, 2019a). Alliance’s call for a People’s Vote - its number one priority as set out in its European manifesto (Alliance Party, 2019b) - was roundly criticised by Brexiteer candidates during the debates. Diane Dodds put to it to Long that she was essentially forcing the electorate to vote ‘again and again and again’ until they returned her preferred answer. Jim Allister likened the call for a People's Vote to a child's insistence on replaying a game because it did not like the result. Long's response, that the 2016 referendum was not a fair contest because it broke 
electoral law and lacked transparency over campaign finance, will have resonated with opponents of the DUP, given that the party has been implicated in a Brexit 'dark money' scandal (Fitzpatrick, 2018). In the event of Brexit going ahead, Alliance emphasised the importance of 'banking the backstop', not only to avoid a hard border but also because it could provide Northern Ireland with a competitive economic advantage by facilitating access to both the UK and EU markets (Alliance Party, 2019a).

The economic merits of the backstop were also extolled by the SDLP, whose manifesto argued that it could provide local businesses in Northern Ireland 'with ambidextrous trading opportunities' (SDLP, 2019). Like the Alliance Party, though, the backstop was very much portrayed as the SDLP's 'Plan B' in this election. The big-ticket item of party leader and MEP hopeful Colum Eastwood was to stop Brexit altogether by pushing for a People's Vote. Launching his campaign with a bid to reclaim the seat once held by SDLP founding member John Hume, Eastwood toured Northern Ireland on an 'anti-Brexit battle bus' emblazoned with the slogan 'Europe sends us €500 million a year: Take back control of your future' (Walker, 2019). ${ }^{\text {xiii }}$ In the televised debates, Eastwood emphasised the unambiguously pro-European history of his party, noting that the SDLP was the most proRemain party in the race and that Europe was 'in [its] DNA'. If this was a subtle dig at rival Sinn Féin, Eastwood needed to do more to land the blow. In media interviews elsewhere, he highlighted Sinn Féin’s record as an 'anti-Europe’ party and pointed out, for example, that it failed to register with the Electoral Commission in 2016 as an official campaigner for Remain (Kelly, 2019). However, perhaps not wanting to deter Sinn Féin voters from transferring preferences his way, Eastwood did not take the opportunity to put these criticisms directly to Martina Anderson on air.

Whereas Eastwood’s campaign was built on aspiration, Sinn Féin’s Martina Anderson had the advantage of experience, having served as MEP since 2014 after topping the poll with 
25.5 percent of the vote. Anderson's campaign made much of Sinn Féin’s record in Europe fighting for 'special status' for Northern Ireland. Her EU election broadcast attributed the inclusion of the backstop in the Withdrawal Agreement ‘to the hard work of Sinn Féin’ and to the lobbying efforts of its MEPs who 'influenc[ed] the position of the Dublin Government and the EU27' (Sinn Féin, 2019a). These claims, repeated on social media, drew criticism for exaggerating Sinn Féin's role. Anderson responded that, as coordinator and lead negotiator of the European United Left's Brexit Working Group, she had refused to sign off on the European Parliament's response to the triggering of Article 50 until its resolution included support for 'preserving the Good Friday Agreement in all its parts' ${ }^{\text {iv }}$ Others, including the DUP's Diane Dodds, were keen to point out that the European Commission and European Council steered negotiations with the UK, not the European Parliament. To many voters, this distinction was likely of little importance. Since making headlines for telling Theresa May to 'stick' the Irish border 'where the sun doesn't shine' (BBC News, 2017), Anderson has established herself as one of the most vocal advocates of 'special status' for Northern Ireland, and was keen to stress this point throughout her campaign.

The Good Friday Agreement (GFA), Northern Ireland’s 1998 peace accord, featured prominently in the campaign rhetoric of both nationalist parties. Since EU citizenship flows from Irish citizenship, Sinn Féin argued that the removal of EU citizenship from people in Northern Ireland would constitute an attack on their rights guaranteed by the GFA (Sinn Féin, 2019b). ${ }^{\mathrm{xv}}$ The SDLP made the case that a hard border would undermine the sense of belonging which Irish citizens have enjoyed in Northern Ireland since the peace process and, moreover, would threaten their 'frictionless freedoms' to live and work across Ireland (SDLP, 2019). What set Sinn Féin and the SDLP apart in this race was their respective positions on a 'People's Vote'. Whereas the SDLP's Colum Eastwood consistently voiced support for a second UK-wide referendum on EU membership, with the aim of securing a majority for 
Remain, there were no such calls from Sinn Féin's Martina Anderson. Added to the fact that the party’s EU manifesto omitted any mention of a People’s Vote, it is clear that Sinn Féin is less than enthusiastic about overturning Brexit via a second referendum. This difference in approach was under-explored during the campaign. The comments of Sinn Féin’s Michelle O’Neill - that Brexit could lead to the ending of partition (Irish Examiner, 2019) - might lead some to the conclusion that, whilst continuing to criticise the Brexit project, the party sees strategic advantage in its outworking.

\section{Results}

As with all previous elections to the European Parliament for the Northern Ireland constituency, the voting system was the Single Transferable Vote (STV), a form of proportional representation (PR) that allows voters to rank candidates in order of preference. ${ }^{\text {xvi }}$ A total of 577,275 votes were recorded, representing a turnout of 45.1 percent down 6.7 points on the 2014 European election and down 7.6 points on the local elections that took place just three weeks earlier. To place this decline in context it is important to note that the 2014 European election had been held concurrently with local elections, likely producing a higher baseline (see Hainsworth and McCann, 2014). Compared to the last standalone European election (in 2009), turnout was up from a record-low of 42.8 percent (see Hainsworth and McCann, 2010). Moreover, compared to the rest of the UK in 2019, Northern Ireland's turnout was significantly higher than the national average of 37 percent; indeed, it was the highest of any UK constituency. Of all votes recorded, 572,447 were deemed valid, producing a quota of 143,112.

[Table 1 about here] 
[Table 2 about here]

For the first time in a European election in Northern Ireland, none of the candidates reached the quota on the first count, reflecting a particularly competitive contest in which transfers would play a decisive role. Sinn Féin’s Martina Anderson topped the poll, securing 22.1 percent of first preferences (see Table 1). However, the 3.3 percentage point decline on her 2014 vote share plus a low rate of transfers left Anderson waiting until the fifth (and final) count to get elected (see Table 2). While this will have been a somewhat disappointing result for the party, its performance in Northern Ireland was considerably stronger than in concurrent elections in the Republic of Ireland (see ... in this issue). ${ }^{\text {xii }}$ Meanwhile, the DUP's Diane Dodds emerged behind Anderson on the first count, but benefited from a reliable supply of transfers from excluded unionist candidates to see her returned first as an MEP on the third count. The modest increase in the DUP's first preference vote share will have come as a relief to the party, suggesting solid support for its pro-Leave, anti-backstop Brexit position among its grassroots supporters.

By far the most remarkable result was the performance of Naomi Long, building on Alliance's momentum from the preceding local elections. The limited polling conducted by LucidTalk before the European election suggested that Long was locked in a three-way race to take the third seat, up against the UUP's Danny Kennedy and the SDLP's Colum Eastwood (McMordie, 2019). In the end, she received 18.5 percent of first preferences comfortably ahead of her nearest rivals, and only a few percentage points behind the DUP and Sinn Féin. This was Alliance's highest share of the vote in any election that it has contested since its foundation in 1970. Moreover, Long attracted a steady rate of transfers from across the political spectrum. Of particular note was that nearly twice as many of 
Eastwood's transfers went to Long over Anderson, allowing Alliance to take the second MEP seat and leaving Sinn Féin finishing in third place.

The UUP's performance was also something of a surprise; few would have expected its candidate to finish in sixth place - behind the TUV's Jim Allister. Receiving just 9.3 percent of first preferences, the lowest overall vote share recorded by the party in any election that it has contested, Danny Kennedy failed to defend the seat held by the UUP in the European Parliament since 1979. Having bolstered its Brexit credentials by opposing both a second referendum and any form of exit that would treat Northern Ireland differently from the rest of the UK, the UUP may have been successful in preventing a significant swing to the DUP (or to the TUV). However, by pivoting towards a relatively large, but limited, pool of unionist Leave voters, the views of unionists who voted Remain in the 2016 referendum were largely ignored. While a majority of unionists (60 percent) voted to Leave in the 2016 referendum, a large minority (40 percent) opted to Remain (Garry, 2016a). With no unionist party clearly representing the preferences of the latter, and with the enduring salience of these referendum divisions, it appears many of these neglected voters were drawn to the proRemain Alliance Party - likely for the first time. In contrast, the vast majority of nationalist voters supported Remain in the 2016, and their referendum preferences were largely reflected by the electoral positions of both main nationalist parties (ibid). This helps to explain why, in the nationalist bloc, the SDLP did not face the same strategic difficulties and resulting decline in vote share as the UUP; in fact, helped by a strong campaign, Colum Eastwood was able to marginally improve his party’s performance on the previous election.

The other six candidates received less than 15 percent of first preferences between them. Two-thirds of these went to Jim Allister, the leader of the TUV and former DUP MEP, who continues to receive a large personal vote. Allister has stood for the TUV in every European Parliament election since 2009; the party's performance in each has been 
consistently stronger than in elections at any other level of government. The Green Party's Clare Bailey secured 2.2 percent of first preferences, broadly matching its level of support in council elections earlier in the month. Along with the Greens, only two other parties fielded a candidate in every European Parliament constituency of the UK: UKIP and the Conservatives. Both of these parties recorded their lowest share of the vote in Northern Ireland, reflecting the region's distinct party system. It is likely for this reason that the newly founded Brexit Party chose not to put forward a candidate, following the longstanding tradition of the Labour Party and the Liberal Democrats to abstain from, rather than challenge, Northern Ireland’s ethno-national politics (see Garry, 2016b).

The results do, however, raise questions over the direction of Northern Ireland's party system. In particular, while the ethno-national dimension clearly continues to structure electoral competition to a significant extent, it played a less dominant role in this election compared to previous European contests. Of all valid votes cast, only 42.9 percent went to a unionist candidate, down from 50.9 percent in 2014. This is not the first time that the combined number of unionist first preferences has dipped below a majority; they totalled 49.0 percent in 2009 and 48.6 percent in 2004. Moreover, the decline in the total number of unionist first preferences was not accompanied by a rise in support for nationalist candidates. Sinn Féin and the SDLP received 35.9 percent of all first preferences between them in 2019 also down from 2014, when the combined nationalist vote share was 38.5 percent. In contrast, 21.2 percent of first preferences went to candidates aligned with neither nationalism nor unionism - more than double the percentage from the previous election (10.5 percent), and the highest the figure has ever been in a European election. Finally, beyond the structures of party system, the actors themselves rendered the result unprecedented: all of the successful candidates were women. Northern Ireland was the only constituency in the UK where this was the case. 


\section{Conclusion}

The DUP’s campaign message in the 2019 European election neatly captures the thrust of the results in Northern Ireland, albeit not in the sense the party would have intended. Referring to the UK's referendum decision to leave the EU three years prior, the party called on voters to 'Tell Them Again!' It seems that voters did indeed respond, reminding the DUP - and any interested observers in London or Brussels - that a majority of voters in Northern Ireland had supported the UK remaining in the EU in 2016 and continue to do so. With Northern Ireland's interests featuring so prominently in the discourse around the UK's withdrawal from the EU, combined with the DUP's considerable influence in national politics, the election results emphasise that the DUP's perspective is a minority one within Northern Ireland itself.

In total, 57 percent of voters supported a candidate explicitly calling for the UK (or at least Northern Ireland) to remain in the EU, either through a second referendum or through revoking the withdrawal process altogether. These positions are now advocated by two of Northern Ireland's three MEPs, representing a symbolically important shift that closely reflects the referendum result in the region three years earlier. While small in number in a European Parliament comprising 751 representatives, and with their mandate set to expire upon the UK's exit, their views nonetheless deserve attention to the extent that Northern Ireland's interests continue to be relevant in shaping the manner of the UK's exit.

Crucially, when it comes to the specific form that Brexit takes, the election results also signal a mandate for the provisions of the Withdrawal Agreement negotiated between the UK and the EU: all pro-Remain candidates explicitly support the backstop arrangements for Northern Ireland in the event of the UK's departure from the EU, and all explicitly oppose the prospect of the UK exiting without a deal. These results echo polling data showing significant support for Northern Ireland leaving the EU on different terms to Great Britain if 
such arrangements prevent a hard border with the Republic of Ireland (Pow, 2019). This apparent endorsement of the Withdrawal Agreement does not chime with the broader narrative of this European Parliament election. In much of Great Britain there was a clear surge in support for parties at either end of the Leave-Remain spectrum, with strong performances by the Brexit Party and the Liberal Democrats respectively. These results indicate a polarised electorate, with little appetite for compromise. The same cannot be said for Northern Ireland, the only European Parliament constituency in the UK where a majority of newly elected MEPs have expressed their support for the Withdrawal Agreement, even if it is not their first preference.

It should be acknowledged, of course, that a significant number of voters in Northern Ireland, predominantly unionists, did vote to leave the EU in 2016 (Garry, 2016a). The DUP's level of support suggests that many would do so again, endorsing the party's insistence that the UK must leave the EU, and sharing its unrelenting opposition to the backstop. Its voters, along with many voters of the UUP, TUV and UKIP, presumably do not see Brexit itself as a threat to the Union with Great Britain, or else they perceive a differentiated exit for Northern Ireland as posing a greater threat to the UK's long-term future. In the wake of the European election, a consensus emerged among candidates vying to succeed Theresa May as Conservative Party leader (and Prime Minister) that the backstop must be dropped from the Withdrawal Agreement, or else the UK will leave without a deal. The DUP, whose MPs at Westminster continue to hold the balance of power, welcomed this new approach (Weaver, 2019). The extent to which unionist interests are served by pursuing this kind of Brexit will soon be put to the test.

Moving beyond the immediate issue of the UK's withdrawal from the EU, it appears that Brexit has helped to open up some new space in Northern Ireland's political landscape. The ethno-national dimension continues to predominate electoral competition, but while the 
Leave-Remain cleavage largely reinforces the underlying unionist-nationalist cleavage, the imperfect alignment of these two dimensions provided the Alliance Party with a strategic opportunity. The party appears to have attracted the support of a significant number of proRemain and socially liberal unionist voters, largely unrepresented by the pro-Leave and socially conservative positions associated with each of the unionist parties. In addition, the high rate of transfers from the SDLP affirms the cross-community nature of the Alliance Party's support. The fact that more than one in five first preferences went to a party unaligned with either unionism or nationalism is noteworthy, but perhaps unsurprising when considered alongside broader attitudinal trends. Since 2006, the annual Northern Ireland Life and Times Survey has found that a plurality of respondents self-identify as neither nationalist nor unionist, reaching 50 percent for the first time in 2018 (Ark, 2019). Prior to the European (and local) elections of 2019, these attitudinal trends on ethno-national ideology had not been accompanied by any major structural changes in voting behaviour. Looking ahead, the key question is whether the 'neither' bloc will present a sustained challenge to the longstanding dominance of the unionist and nationalist blocs, or whether its relative influence will recede in a party system still fundamentally structured along the ethno-national dimension. 


\section{References}

Alliance Party (2019a) Better Together - Alliance European Election 2019 Broadcast, available at: https://www.youtube.com/watch?v=jeyRHrc6_4w (accessed 1 July 2019).

Alliance Party (2019b) Alliance Party European Election Manifesto 2019, available at: https://d3n8a8pro7vhmx.cloudfront.net/allianceparty/pages/3559/attachments/original/15 57772505/ManifestoEPNIonline.pdf?1557772505 (accessed 1 July 2019).

Ark (2019) Northern Ireland Life and Times Survey, available at: http://www.ark.ac.uk/nilt/2018/ (accessed on 1 July 2019).

BBC News (2019a) SDLP Members Back Fianna Fáil Partnership, available at: https://www.bbc.com/news/uk-northern-ireland-47179888 (accessed 1 July 2019).

BBC News (2019b) Brexit: UK will Take Part in European Elections, Says David Lidington, available at: https://www.bbc.co.uk/news/uk-politics-48188951 (accessed 1 July 2019).

BBC News (2017) ‘Stick Border Where Sun Doesn't Shine’ says Martina Anderson, available at https://www.bbc.co.uk/news/av/uk-northern-ireland-39269305/stick-border-wheresun-doesn-t-shine-says-martina-anderson (accessed 1 July 2019).

Bradshaw, P. (2019) Tweet, 4 May, available at: https://twitter.com/PaulaJaneB/status/1124598655753891840 (accessed 1 July 2019).

Devenport, M. (2018) Stormont: No Guinness Record for Political Ineptitude, BBC News, 20 August, available at: https://www.bbc.co.uk/news/uk-northern-ireland-45244330 (accessed 1 July 2019).

DUP (2019a) European Election Manifesto 2019, available at: http://www.mydup.com/images/uploads/publications/European_manifesto___Final.pdf (accessed 1 July 2019).

DUP. (2019b) DUP Party Election Broadcast - European Election. Available at https://www.youtube.com/watch?v=tAsF8meQy30 (accessed 1 July 2019).

Financial Times (2019) Brexit Makes the Case for an Independent Scotland, 1 May, available at: https://www.ft.com/content/a05dd0ce-6c10-11e9-80c7-60ee53e6681d (accessed 1 July 2019).

Fitzpatrick, J. (2018) BBC Spotlight: Brexit, Dark Money and the DUP, BBC News, 27 June, available at: https://www.bbc.co.uk/news/uk-northern-ireland-44624299 (accessed 1 July 2019).

Garry, J. (2016a) The EU Referendum Vote in Northern Ireland: Implications for our Understanding of Citizens' Political Views and Behaviour, available at 
https://www.qub.ac.uk/brexit/Brexitfilestore/Filetoupload,728121,en.pdf $\quad$ (accessed 1 July 2019).

Garry, J. (2016b) Consociation and Voting in Northern Ireland: Party Competition and Electoral Behavior. Philadelphia, PA: University of Pennsylvania Press.

Hainsworth, P. \& McCann, G. (2010) 'Ringing Some Changes: The 2009 European Election in Northern Ireland', Irish Political Studies 25 (2), pp 303-314.

Hainsworth, P. \& McCann, G. (2014) 'The Renewal of Mandates: The 2014 European Election in Northern Ireland', Irish Political Studies 29 (4), pp 590-602.

Haughey, S. (2017) Extra-parliamentary behaviour in Northern Ireland: MLAs and constituency service, The Journal of Legislative Studies, 23(4), pp. 529-548.

Hennessey, T., Braniff, M., Mcauley, J., Tonge, J., \& Whiting, S. (2014) The Ulster Unionist Party: Country Before Party. Oxford: Oxford University Press.

Hughes, B. (2019) DUP Slammed for Sharing Pro-Brexit Video Using Troubles Bomb Footage, Irish News, 24 May, available at: https://www.irishnews.com/news/northernirelandnews/2019/05/24/news/dup-slammedfor-sharing-pro-brexit-video-using-troubles-bomb-footage-1627441// (accessed 1 July 2019).

Irish Examiner (2019) Seize Brexit Opportunity to End Partition, urges Sinn Féin, 21 January, available at: https://www.irishexaminer.com/breakingnews/ireland/seize-brexitopportunity-to-end-partition-urges-sinn-fein-899153.html (accessed 1 July 2019).

Kelly, B. (2019) Northern Ireland Must Use EU Elections as ‘People’s Vote’ on Brexit, Says SDLP Leader, The Independent, 27 April, available at: https://www.independent.co.uk/news/uk/politics/eu-elections-eastwood-northern-irelandsdlp-mep-brexit-remain-a8889116.html (accessed 1 July 2019).

Kennedy, D. (2016) Danny Kennedy: It is in the Interests of Unionism as a whole for the UK to Stay in the EU, News Letter, 17 June, available at: https://www.newsletter.co.uk/news/opinion/danny-kennedy-it-is-in-the-interests-of-theunionism-as-a-whole-for-the-uk-to-stay-in-the-eu-1-7435959 (accessed 1 July 2019).

Manley, J. (2017) SDLP Calls for Nationalist Voices from Across the UK at Brexit Talks, Irish News, 14 December, available at: https://www.irishnews.com/news/2017/12/14/news/colum-eastwood-seeks-devolvedadministrations-support-for-stormont-parties-seat-on-joint-ministerial-council-1210215/ (accessed 1 July 2019). 
McCormack, J. (2019) Brexit: Call for Irish Border Poll during Deadlock 'Irresponsible', BBC News, 13 February, available at: https://www.bbc.co.uk/news/uk-northern-ireland$\underline{47227297}$ (accessed 1 July 2019).

McGrath, C. (2019) Brexit Breakthrough: 'Frustrated' Northern Ireland Farmers Demand DUP Backs May's Deal, The Express, 18 March, available at: https://www.express.co.uk/news/politics/1101737/brexit-news-northern-ireland-farmersdup-theresa-may-no-deal-article-50 (accessed 1 July 2019).

McMordie, J. (2018) LucidTalk Poll: DUP Continue to Sow Seeds of their own Downfall, Northern Slant, 15 December, available at: https://www.northernslant.com/lucidtalkpoll-dup-continue-to-sow-seeds-of-their-own-downfall/ (accessed 1 July 2019).

McMordie, J. (2019) The Long Path to Brussels? Northern Slant, 13 May, available at: https://www.northernslant.com/the-long-path-to-brussels/ (accessed 1 July 2019).

Mowat, L. (2019) After Three Years of Attacking Mrs May’s Brexit Deal Rees-Mogg Capitulates to the PM, The Express, 27 May, available at: https://www.express.co.uk/news/politics/1105890/brexit-news-latest-eu-deal-theresamay-jacob-rees-mogg-DUP (accessed 1 July 2019).

O’Carroll, L. (2019) Northern Ireland Business Leaders Press MPs to Back Brexit Deal, The Guardian, 28 January, available https://www.theguardian.com/politics/2019/jan/28/northern-ireland-business-leaderspress-mps-to-back-brexit-deal (accessed 1 July 2019).

Pow, J. (2019) Brexit and Public Opinion: Northern Ireland, available at: https://ukandeu.ac.uk/brexit-and-public-opinion-northern-ireland/ (accessed 1 July 2019).

SDLP (2019) Protecting our Peace, Stopping Borders, Banking the Backstop, available at: https://www.sdlp.ie/site/assets/files/43536/protecting_our_peace.pdf (accessed 1 July 2019).

Sinn Féin (2019a) Martina Anderson EU Election Broadcast, available at: https://www.youtube.com/watch?v=L9NZXLCdByc (accessed 1 July 2019).

Sinn Féin (2019b) Brexit Incompatible with the Good Friday Agreement - Ó Donnghaile, available at: https://www.sinnfein.ie/contents/52631 (accessed 1 July 2019).

Tonge, J. (2016) The Impact of Withdrawal from the European Union upon Northern Ireland, Political Quarterly, 87(3), pp. 338-342.

Tonge, J. (2017a) The Impact and Consequences of Brexit for Northern Ireland, briefing to the European Parliament, available at: 
http://www.europarl.europa.eu/RegData/etudes/BRIE/2017/583116/IPOL_BRI\%282017 \%29583116_EN.pdf (accessed 1 July 2019).

Tonge, J. (2017b) Supplying Confidence or Trouble? The Deal Between the Democratic Unionist Party and the Conservative Party, The Political Quarterly, 88(3), pp. 412-416.

Tonge, J. (2019) Outcome Looks Grim for UUP, but DUP's Vote Share Rose... and the Centre Ground Really Does Exist, Belfast Telegraph, May 4, available at: https://www.belfasttelegraph.co.uk/opinion/news-analysis/jon-tonge-outcome-looksgrim-for-uup-but-dups-vote-share-rose-and-the-centre-ground-really-does-exist38077487.html (accessed 1 July 2019).

UUP (2019) Ulster Unionist Party 2019 European Manifesto, available at: https://uup.org/assets/images/2019\%20European\%20Manifesto.pdf (accessed 1 July 2019).

Walker, S. (2019) Colum Eastwood: 'Brexit Can Still be Stopped', BBC News, 8 May, available at: https://www.bbc.co.uk/news/uk-northern-ireland-48206796 (accessed 1 July 2019).

Weaver, M. (2019) DUP Welcomes Tory Leadership Contenders’ Vow to Ditch Backstop, The Guardian, 2 July, available at: https://www.theguardian.com/politics/2019/jul/02/dup-welcomes-tory-leadershipcontenders-vow-to-ditch-backstop (accessed 2 July 2019). 


\begin{tabular}{|c|c|c|c|c|c|}
\hline Party & $\begin{array}{l}\text { First preferences, } 2019 \\
\text { (\% share) }\end{array}$ & $\begin{array}{l}\text { First preferences, } 2014 \\
\text { (\% share) }\end{array}$ & $\begin{array}{l}\text { Percentage point } \\
\text { difference }\end{array}$ & $\begin{array}{l}\text { Campaign position on } \\
\text { Brexit }\end{array}$ & $\begin{array}{l}\text { Campaign position on } \\
\text { Withdrawal Agreement }\end{array}$ \\
\hline Sinn Féin & 22.2 & 25.5 & -3.3 & Remain & Support \\
\hline DUP & 21.8 & 20.9 & +0.9 & Leave & Oppose \\
\hline Alliance & 18.5 & 7.1 & +11.4 & Remain & Support \\
\hline SDLP & 13.7 & 13.0 & +0.7 & Remain & Support \\
\hline TUV & 10.8 & 12.1 & -1.3 & Leave & Oppose \\
\hline UUP & 9.3 & 13.3 & -4.0 & Leave & Oppose \\
\hline Green Party & 2.2 & 1.7 & +0.5 & Remain & Support \\
\hline UKIP & 0.9 & 3.9 & -3.0 & Leave & Oppose \\
\hline $\begin{array}{l}\text { Conservative \& } \\
\text { Unionist }\end{array}$ & 0.1 & 0.7 & -0.6 & Leave & Support \\
\hline Other & 0.5 & 1.7 & -1.2 & - & - \\
\hline
\end{tabular}

Table 1: Share of first preferences by party in the 2014 and 2019 European elections.

Source: The Electoral Office for Northern Ireland (EONI) https://www.eoni.org.uk/Elections/Election-results-and-statistics/Election-results-and-statistics-2003-onwards 


\begin{tabular}{|c|c|c|c|c|c|c|c|c|c|c|c|}
\hline \multirow{5}{*}{ Candidate } & \multirow{5}{*}{ Party } & \multirow{5}{*}{ Stage 1} & \multirow{2}{*}{\multicolumn{2}{|c|}{$\begin{array}{c}\text { Stage } 2 \\
\text { Exclude }\end{array}$}} & \multicolumn{2}{|c|}{ Stage 3} & \multicolumn{2}{|c|}{ Stage 4} & \multicolumn{2}{|c|}{ Stage 5} & \multirow{5}{*}{$\begin{array}{l}\text { Final } \\
\text { Result }\end{array}$} \\
\hline & & & & & \multicolumn{2}{|c|}{ Exclude } & \multicolumn{2}{|c|}{ Transfer } & \multicolumn{2}{|c|}{ Exclude } & \\
\hline & & & \multicolumn{2}{|c|}{$\begin{array}{l}\text { Bhogal, McCann, } \\
\text { Morrice, Hill, Bailey }\end{array}$} & \multicolumn{2}{|c|}{ Kennedy } & \multicolumn{2}{|c|}{ Dodds } & \multicolumn{2}{|c|}{ Eastwood } & \\
\hline & & & \multicolumn{2}{|c|}{ Result } & \multicolumn{2}{|c|}{ Result } & \multicolumn{2}{|c|}{ Result } & \multicolumn{2}{|c|}{ Result } & \\
\hline & & & Transferred & Total & Transferred & Total & Transferred & Total & Transferred & Total & \\
\hline Jim Allister & TUV & 6202 & 1851.00 & 63872.00 & 15668.00 & 79540.00 & 10314.00 & 89854.00 & 225.00 & 90079.00 & - \\
\hline Martina Anderson & Sinn Féin & 126951 & 1166.00 & 128117.00 & 73.00 & 128190.00 & 10.50 & 128200.50 & 24236.00 & 152436.00 & $\begin{array}{l}\text { Elected } \\
\text { (1) }\end{array}$ \\
\hline Clare Bailey & Green Party & 12471 & -12471.00 & & & & & & & & - \\
\hline $\begin{array}{l}\text { Amandeep Singh } \\
\text { Bhogal }\end{array}$ & $\begin{array}{l}\text { Conservative \& } \\
\text { Unionist }\end{array}$ & 662 & -662.00 & & & & & & & & - \\
\hline Diane Dodds & DUP & 124991 & 2300.00 & 127291.00 & 28131.00 & 155422.00 & -12310.00 & 143112.00 & & 143112.00 & $\begin{array}{l}\text { Elected } \\
\text { (3) }\end{array}$ \\
\hline Colum Eastwood & SDLP & 78589 & 2360.00 & 80949.00 & 1152.00 & 82101.00 & 312.50 & 82413.50 & -82413.50 & & - \\
\hline Robert Hill & UKIP & 5115 & -5115.00 & & & & & & & & - \\
\hline Danny Kennedy & UUP & 53052 & 1684.00 & 54736.00 & -54736.00 & & & & & & - \\
\hline Naomi Long & Alliance & 105928 & 9399.00 & 115327.00 & 6936.00 & 122263.00 & 1654.00 & 123917.00 & 46453.00 & 170370.00 & $\begin{array}{c}\text { Elected } \\
(2)\end{array}$ \\
\hline Neil McCann & Independent & 948 & -948.00 & & & & & & & & - \\
\hline \multirow[t]{3}{*}{ Jane Morrice } & Independent & 1719 & -1719.00 & & & & & & & & - \\
\hline & $\begin{array}{l}\text { Non- } \\
\text { transferable }\end{array}$ & & 2155.00 & 2155.00 & 2776.00 & 4931.00 & 19.00 & 4950.00 & 7675.00 & 12625.00 & \\
\hline & Totals & & & 572447.00 & & 572447.00 & & 572447.00 & & 568622.00 & \\
\hline
\end{tabular}

Table 2: Results of each stage of the 2019 European election count

Source: The Electoral Office for Northern Ireland (EONI) https://www.eoni.org.uk/getmedia/2d393c0e-ba88-48da-af69-fec342d34be0/European-Election-2019-Result-Sheet 
${ }^{\mathrm{i}}$ Northern Ireland surpassed Belgium's world record for going the longest period of time in peacetime without a government (541 days) in late August 2018. Guinness World Records, however, continue to recognise Belgium as the official record holder because Northern Ireland, as a devolved administration, does not qualify under the organisation's criteria (Devenport, 2018).

ii For the Scottish Government's consideration of Brexit matters see https://www.gov.scot/brexit/; for the Welsh Government see https://gov.wales/brexit (both accessed 17/06/2019). The Northern Ireland Assembly's Research and Information Service last produced a briefing paper on the potential implications of EU withdrawal in May 2017. See http://www.niassembly.gov.uk/globalassets/documents/raise/publications/20172022/2017/economy/3017.pdf (accessed 18/06/2019).

iii Northern Ireland officials can attend as observers. See https:/www.parliament.uk/business/committees/committees-a-z/commons-select/public-administration-andconstitutional-affairs-committee/news-parliament-2017/interparliamentary-forum-brexit-17-19/ (accessed 18/06/2019).

iv Despite there being no functioning Assembly or Executive in Northern Ireland, MLAs continue to be employed in their official capacity as elected representatives. Partly in recognition of the substantial constituency service work they undertake (see Haughey, 2017), MLAs continue to be paid their salary at a reduced rate.

${ }^{\mathrm{v}}$ In exchange for approximately $£ 1$ billion in new funding for Northern Ireland, the DUP pledged the support of its 10 MPs for the Conservative government on key votes, such as those relating to the Queen's Speech, the Budget, and Brexit. See Tonge (2017b).

vi The DUP argue that the backstop, if operational, would create trade barriers between Northern Ireland and Great Britain. This, they argue, is because Northern Ireland would be subject to some EU regulations that would not apply to the rest of the UK (DUP, 2019a).

vii Jacob Rees-Mogg, for example, previously indicated that he would only support the Withdrawal Agreement if DUP support for the deal was also attained (Mowat, 2019).

viii After weeks of uncertainty as to whether the UK would in fact participate, the government finally conceded on $7^{\text {th }}$ May 2019 that, with the exit date delayed until $31^{\text {st }}$ October, the country was legally obliged to hold European elections on $23^{\text {rd }}$ May (BBC, 2019b).

ix In the context of Northern Ireland politics, the term 'centre ground' tends to refer to voters and parties who are neither nationalist nor unionist. It is an imperfect term given that some of these parties - such as the Green Party - are patently left of centre on other dimensions.

x This exchange took place in a debate broadcast on BBC Northern Ireland's The View on 16th May 2019. Available at https://www.youtube.com/watch?v=q4RzDyyWmt8 (accessed 16/06/2019).

${ }^{x i}$ Most UUP MLAs and the majority of its 100-strong ruling Executive supported Remain. Notably, however, party grandees such as David Trimble backed Leave, as did over 40 percent of UUP members (see Hennessey et al. 2019: 81).

xii The UTV debate was broadcast on $13^{\text {th }}$ May 2019, and is available at

https://www.itv.com/utvprogrammes/view-from-stormont/view-from-stormont-episode-101 (accessed 27/06/2019).

xiii This was a reference to the misleading message displayed on a Leave campaign bus prior to the 2016 referendum: 'We send the EU £350 million a week; let’s fund our NHS instead'.

xiv See Paragraph O of European Parliament resolution (5th April 2017) on negotiations with the United Kingdom (2017/2593(RSP)). It is available at http://www.europarl.europa.eu/doceo/document/TA-8-20170102_EN.html (accessed 20/06/2019).

${ }_{\mathrm{xv}}$ The Good Friday Agreement has a provision that entitles citizens born in Northern Ireland to identify as Irish, British or both.

xvi STV is used in all elections in Northern Ireland except for Westminster, which are conducted using first-pastthe-post.

xvii Along with the Green Party, Sinn Féin is the only party to compete in elections on both sides of the border. The SDLP entered a 'partnership' with Fianna Fáil early in 2019, but the arrangement does not constitute a formal merger (BBC News, 2019a). 